\title{
Erratum to: Development and validation of an ultra- performance liquid chromatography tandem mass spectrometry (UPLC-MS/MS) method for the quantitative determination of rhamnolipid congeners
}

Michelle Rudden $^{1} \cdot$ Konstantina Tsaousi $^{1} \cdot$ Roger Marchant $^{1} \cdot$ Ibrahim M. Banat $^{1}$ •

Thomas J. Smyth ${ }^{2,3}$

Published online: 15 September 2015

(C) Springer-Verlag Berlin Heidelberg 2015

Erratum to: Appl Microbiol Biotechnol

DOI 10.1007/s00253-015-6837-1

The original version of this article inadvertently contained mistake. In the author list, the correct name should have been "Konstantina Tsaousi" instead of "Konstantina Tsauosi".

The correct presentation is as shown above.

The online version of the original article can be found under doi:10.1007/ s00253-015-6837-1.

Thomas J. Smyth

smyth.thomas@itsligo.ie

1 School of Biomedical Science, Ulster University,

Coleraine, Northern Ireland, UK

2 Department of Life Sciences, Institute of Technology Sligo, Co., Sligo, Republic of Ireland

3 Teagasc Food Research Centre Ashtown, Dublin, Ireland 